\title{
EP-105
}

\section{Laboratory healthcare gap of hepatitis B care in Yogyakarta, Indonesia}

\author{
Arum Tri WAHYUNINGSIH ${ }^{* 1}$, Osman SIANIPAR', Adika Zhulhi ARJANA', Rhaina KHAIRANI', Romi Ade SELSATA2 \\ Fadhilah Khairuna LARASATI ${ }^{2}$, Alfin Herjuno DWIPUTRO ${ }^{2}$, Intan Susmita RAFSANJANI ${ }^{3}$, Budi MULYONO'
}

'Clinical Pathology and Laboratory Medicine, Faculty of Medicine Public Health and Nursing, Universitas Gadjah Mada, Yogyakarta, Indonesia ${ }^{2}$ Medical Doctor Programme, Faculty of Medicine Public Health and Nursing, Universitas Gadjah Mada, Yogyakarta, Indonesia ${ }^{3}$ Medical Doctor Programme, Faculty of Medicine, Universitas Islam Indonesia, Yogyakarta, Indonesia

Introduction: Serological markers of hepatitis B virus (HBV) infection (HBsAg, anti-HBs, hepatitis B envelope antigen [HBeAg], anti-HBe, and anti-hepatitis B core $[\mathrm{HBc}] \mathrm{IgM} / \mathrm{IgG}$ ) was used as the basis for diagnosis and differences in the chronicity of hepatitis B infection. This study aims to explore the laboratory healthcare gap of the patient with hepatitis B infection in our setting and whether laboratory data completeness affects the results.

Methods: This study used retrospective data taken from the Medical Records of hepatitis B patients at Dr. Sardijto Hospital in 2020. The subjects in this study were hepatitis B patients with positive HBsAg. The exclusion criteria were individuals who had co-infection with the hepatotropic virus or HIV. This study was funded by Deputi Bidang Penguatan Riset dan Pengembangan, Kementerian Riset dan Teknologi/Badan Inovasi Nasional.

Results: A total of 232 patients were included in the study. All patients underwent HBsAg examination and tested positive, with $65.09 \%$ of subjects had HBV DNA examination. HBeAg examination result was only found in $18 \%$ of patients. Anti HBc examinations were only found in 2 patients. No subjects were examined for anti-HBs in this study. The proportion of subjects examined for the liver function was still low (<50\%), with the most widely checked parameters are AST and ALT while other parameters are very rare.

Conclusions: The utilization of serological tests and hepatic function in hepatitis B patients in Yogyakarta, Indonesia is still low. Intervention and financial support are needed to improve the quality of life of patients with hepatitis B who were treated. 